\title{
Thyroid peroxidase antibody positivity among euthyroid pregnant women and its association with foeto-maternal outcome
}

\author{
Kanika Gulati ${ }^{1}$, Manjula Sharma ${ }^{1}$, Rekha Bharti ${ }^{1 *}$, Krishna Biswas ${ }^{2}$, Achla Batra ${ }^{1}$, \\ Abha Aggarwal ${ }^{3}$, Aruna Batra ${ }^{4}$
}

\begin{abstract}
${ }^{1}$ Department of Obstetrics and Gynecology, ${ }^{2}$ Department of Endocrinology, Vardhman Mahavir Medical College and Safdarjung Hospital, New Delhi, India

${ }^{3}$ Rtd. National Institute of Medical Statistics, ICMR, New Delhi, India

${ }^{4}$ Department of Obstetrics and Gynecology, SGT University, Budhera, Gurgaon, Haryana, India
\end{abstract}

Received: 10 March 2018

Accepted: 17 March 2018

\author{
*Correspondence: \\ Dr. Rekha Bharti, \\ E-mail: rekhabharti@gmail.com
}

Copyright: (c) the author(s), publisher and licensee Medip Academy. This is an open-access article distributed under the terms of the Creative Commons Attribution Non-Commercial License, which permits unrestricted non-commercial use, distribution, and reproduction in any medium, provided the original work is properly cited.

\begin{abstract}
Background: Thyroid peroxidase antibody (TPO-Ab) positivity is associated with increased risk of adverse pregnancy outcomes. The present study was planned to find out the prevalence of TPO-Ab and its association with adverse foeto-maternal outcome in euthyroid pregnant women.

Methods: A total of 510 euthyroid pregnant women with $<20$ weeks gestation were recruited from antenatal clinic. Serum TPO-Ab testing was done and women were divided into 2 groups. The study group comprised of TPO-Ab positive women and control group comprised of age and parity matched TPO-Ab negative women, double in number to that of the study group. Repeat Serum TSH was done at term/delivery and women were followed till delivery for foeto-maternal outcome.

Results: The prevalence of TPO-Ab positivity in euthyroid pregnant women was $11.3 \%$. A significant number of women in the study group developed hypothyroidism at term/delivery, $18.61 \%$ vs $7.61 \%$, respectively, $\mathrm{p}=0.02$. None of the women in the study or control group developed gestational diabetes or placental abruption, or had babies with NND or RDS. There was one IUD in the study group, rest of the maternal and foetal outcomes studied were not statistically significant between two the groups. The caesarean section rates in both groups was not statistically different, however, there were more caesarean sections done for foetal distress in the study group, $\mathrm{p}=0.04$.

Conclusions: Thyroid peroxidase positivity is present in $11.3 \%$ of euthyroid women and is associated with an increased risk of developing hypothyroidism during pregnancy. It is not associated with adverse foeto-maternal outcome.
\end{abstract}

Keywords: Euthyroid, Prevalence, Pregnancy, Thyroid peroxidase antibodies, TPO-Ab

\section{INTRODUCTION}

Thyroid peroxidase antibodies (TPO-Ab) are known to be associated with adverse pregnancy outcomes. ${ }^{1,2}$ Although most pregnant women with elevated serum levels of TPO-Ab are clinically and biochemically euthyroid, they may be at increased risk for spontaneous abortion, preterm delivery, and placental abruption. ${ }^{1-3}$ The exact mechanism of this association of adverse outcome with $\mathrm{TPO}-\mathrm{Ab}$ positivity is unknown.

TPO-Ab positivity is found in $5-10 \%$ of pregnant women and is associated with increased risk of developing thyroid dysfunction during pregnancy, after childbirth and in the postpartum period. ${ }^{1-5}$ It is hypothesised that 
euthyroid women with antithyroid antibodies harbour subtle deficiency of thyroid hormones and their thyroid glands are not able to cope up with the increasing demand during pregnancy. Also, presence of autoimmune antibodies may have direct impact on the placental and foetal development leading to poor pregnancy outcome in these women. Other theories proposed for adverse pregnancy outcome include cross-reactivity of antithyoid antibodies with $\mathrm{HCG}$ receptors on zona pellucida and increased cytokine levels in the endometrium. ${ }^{6-9}$

There are no guidelines on routine testing of TPO-Ab in euthyroid pregnant women. Few authors have shown positive pregnancy outcome in euthyroid TPO-Ab positive women when treated with levothyroxine. ${ }^{2,10}$ However there is no consensus on treating these women in the absence of hypothyroidism. ${ }^{9}$ The, Indian Thyroid Association (ITA) recommends routine screening for thyroid dysfunction and thyroid antibodies ideally in preconception period but definitively during early pregnancy. ${ }^{11}$ The present study was designed to find out the prevalence of TPO-Ab and its association with adverse foeto-maternal outcome in euthyroid pregnant women attending the antenatal clinic of tertiary care hospital.

\section{METHODS}

This was a cross sectional study, conducted at a tertiary care centre in the Department of Obstetrics and Gynaecology, in collaboration with the Department of Endocrinology. After taking informed written consent, 510 euthyroid pregnant women with $\leq 20$ weeks pregnancy attending the antenatal clinic, were recruited to study the prevalence of TPO-Ab positivity. The sample size was calculated taking an anticipated prevalence of TPO-Ab positivity as 5\%, including $10 \%$ lost to follow up and absolute margin of error as $0.02 \%$, with $95 \%$ level of confidence. Before starting the study, clearance was taken from the Institutional Ethical Committee. The first 20 euthyroid pregnant women, attending the antenatal clinic on two fixed days in a week, underwent serum $\mathrm{TPO}-\mathrm{Ab}$ testing. The normal non-pregnant range of S.TSH in the standard hospital central laboratory is 0.4$6.2 \mu \mathrm{IU} / \mathrm{ml}$. The TSH reference range taken in this study was $0.3-5.2 \mu \mathrm{IU} / \mathrm{ml}$ and $\mathrm{TPO}-\mathrm{Ab}$ reference range taken was $7.6-27.6 \mathrm{IU} / \mathrm{ml}$. This was done by reducing $0.1 \mathrm{mIU} / \mathrm{L}$ from the lower and $1.0 \mathrm{mIU} / \mathrm{L}$ from the upper reference range of standard hospital reference laboratory values as per recommendation of American Thyroid Association (ATA) Guidelines (2011), and the higher pregnancy specific ranges reported in the Indian population. ${ }^{12,13}$ The serum TSH and TPO-Ab testing was done using ELISA technique.

A detailed history and examination was performed with special regards to maternal age, gestational age, parity, height, weight and BMI. Based on the TPO-Ab antibody positivity women were divided into study and control groups. Study group comprised of euthyroid, TPO-Ab positive pregnant women and the control group comprised of age and parity matched euthyroid TPO-Ab negative women, double in number to that of the study group. The women with known thyroid dysfunction, hypertension, diabetes mellitus, heart disease and collagen disease, and multifetal pregnancy were excluded from the study and control group. The women in study and control groups underwent a repeat serum TSH at term or at delivery if women went into preterm labour. All women were followed up as per the hospital protocol till delivery.

Maternal and foetal outcome measures studied were, Maternal outcomes-Hypothyroidism defined as S TSH $>5.2 \mathrm{mIU} / \mathrm{L}$ at term/delivery; Gestational Hypertension (GHTN) defined as persistently elevated blood pressure of $\geq 140 / 90 \mathrm{~mm} \mathrm{Hg}$ for the first time after mid-pregnancy, without proteinuria; Preeclampsia (PE) defined as persistently elevated blood pressure of $\geq 140 / 90 \mathrm{~mm} \mathrm{Hg}$ for the first time after mid-pregnancy, with proteinuria (24-hour urinary protein exceeding 300mg); Gestational Diabetes (GDM) defined as carbohydrate intolerance of variable severity with onset or first recognition during pregnancy; Placental Abruption defined as premature separation of a normally situated placenta; Preterm Premature Rupture of Membranes (PPROM) defined as the rupture of foetal membranes occurring before 37 weeks of gestation; and foetal outcomes- Miscarriage defined as spontaneous foetal loss before the period of viability ( $<20$ weeks or foetal weight $\leq 500$ grams); Preterm Birth defined as delivery before 37 completed weeks; Intrauterine growth restriction/ small for gestational age (IUGR/SGA) defined as birth weight less than tenth percentile for gestational age; Low APGAR defined as APGAR score $<7$ at 5 minutes; Respiratory Distress Syndrome (RDS) defined as developmental insufficiency of surfactant production and structural immaturity in the lungs. The diagnosis of RDS was based on clinical findings, blood gas analysis and chest x-ray. Stillbirth/Intrauterine foetal demise (IUFD) defined as foetal death occurring after 20 weeks of pregnancy or/with foetal weight >500 grams; Neonatal Deaths (NND) defined as foetal death occurring within first 28 days of life; and need for Neonatal intensive care unit (NICU) admission with indication for admission.

\section{Statistical analysis}

Data was analysed using Pearson Chi square test. The significance level was set at $\mathrm{p}<0.05$. Statistical analysis was performed with SPSS 12.0 for windows.

\section{RESULTS}

During the study, a total of 510 euthyroid pregnant women in the first 20 weeks of gestation attending the antenatal OPD were enrolled to determine the prevalence of TPO-Ab positivity on the basis of serum TPO-Ab estimation. Out of these, 58 women were $\mathrm{TPO}-\mathrm{Ab}$ 
positive, therefore the prevalence of TPO-Ab positivity in euthyroid women was $11.3 \%$.

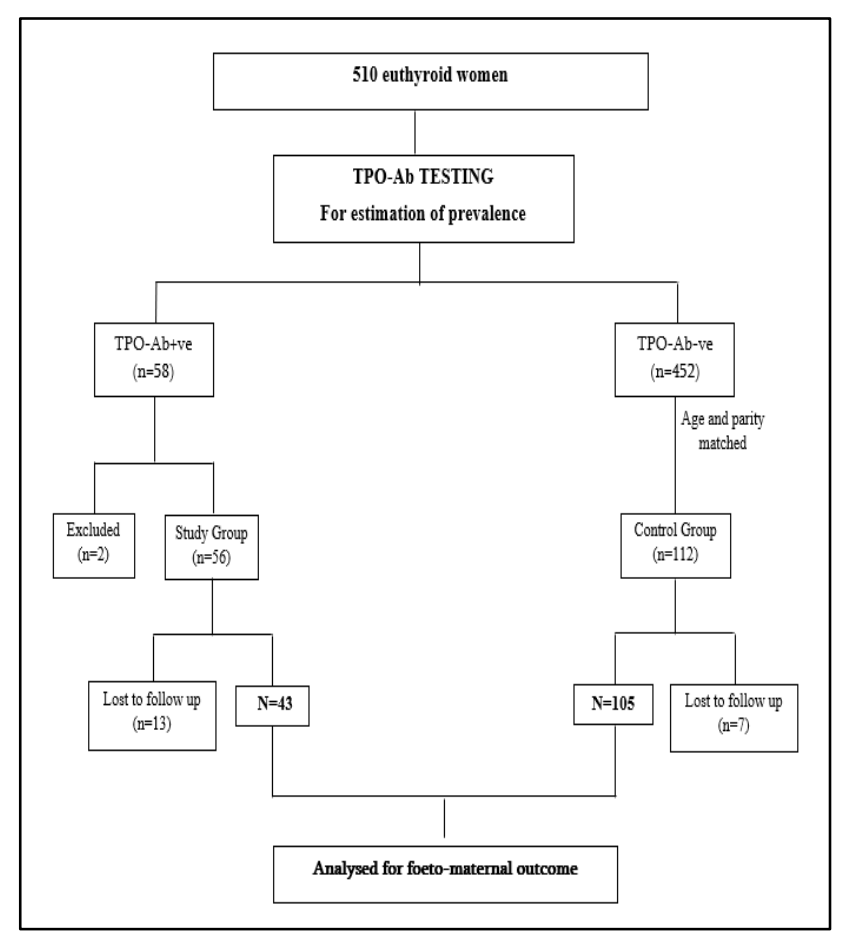

Figure 1: Recruitment of women in the study.

Out of 58 TPO-Ab positive women, 2 were excluded from the study due to the presence of essential hypertension in one and twin gestation in the other. Hence, the study group comprised of the 56 TPO-Ab positive women while the control group comprised of double the number of age and parity matched TPO-Ab negative women $(n=112)$. However, a total of 13 women in the study group and 7 in the control group were lost to follow up, hence foeto-maternal outcome was analysed for 43 women in the study group and 105 women in the control group, Figure 1.

The mean age of women in the study and in control group was 24.47 and 23.17 years, respectively. Majority of women in the study group and control group had normal BMI, 58.14\% and $72.38 \%$, respectively, $\mathrm{p}=0.189$, Table 1.

Statistically significant number of women in the study group developed hypothyroidism $(\mathrm{S}$ TSH $>5.2 \mathrm{mIU} / \mathrm{L})$ at term/delivery, $18.61 \%$ vs $7.61 \%$, respectively, $\mathrm{p}=0.02$. None of the women in the study or control group developed gestational diabetes or placental abruption, or had babies with NND or RDS. There was one IUD in the study group, rest of the maternal and foetal outcomes studied were not statistically significant between the two groups, Table 2. The caesarean section rates in both groups was not statistically different, however, there were more caesarean sections done for foetal distress in the study group, $\mathrm{p}=0.04$, Table 2 .
Table 1: Demographic profile of women in study and control group.

\begin{tabular}{|c|c|c|c|c|}
\hline \multirow{2}{*}{$\begin{array}{l}\text { Demographic } \\
\text { profile } \\
\text { Age }\end{array}$} & \multicolumn{2}{|c|}{$\begin{array}{l}\text { Study group } \\
(n=43)\end{array}$} & \multicolumn{2}{|c|}{$\begin{array}{l}\text { Control group } \\
(\mathrm{n}=105)\end{array}$} \\
\hline & Number & $\%$ & Number & $\%$ \\
\hline$<20$ & 07 & 16.28 & 17 & 16.19 \\
\hline $21-25$ & 23 & 53.49 & 60 & 57.15 \\
\hline $26-30$ & 10 & 23.25 & 23 & 21.90 \\
\hline$\geq 31$ & 3 & 6.98 & 05 & 4.76 \\
\hline \multicolumn{5}{|l|}{ Parity } \\
\hline Primigravidae & 25 & 58.14 & 70 & 66.67 \\
\hline Multigravidae & 18 & 41.86 & 35 & 33.33 \\
\hline \multicolumn{5}{|l|}{ Education } \\
\hline Illiterate & 09 & 20.93 & 13 & 12.38 \\
\hline Primary & 13 & 30.23 & 51 & 48.57 \\
\hline Middle & 21 & 48.84 & 38 & 36.19 \\
\hline Graduate & 00 & 00.0 & 03 & 2.86 \\
\hline \multicolumn{5}{|c|}{ Socio-Economic Status } \\
\hline Lower & 22 & 51.16 & 61 & 58.10 \\
\hline Upper lower & 18 & 41.86 & 39 & 37.14 \\
\hline Lower middle & 03 & 6.98 & 05 & 4.76 \\
\hline Upper middle & 00 & 00.0 & 00 & 00.0 \\
\hline Upper & 00 & 00.0 & 00 & 00.0 \\
\hline \multicolumn{5}{|l|}{ Occupation } \\
\hline House wife & 39 & 90.70 & 100 & 95.24 \\
\hline Self employed & 02 & 4.65 & 03 & 2.86 \\
\hline Professional & 02 & 4.65 & 02 & 1.90 \\
\hline BMI 18.5-24.9 & 25 & 58.14 & 76 & 72.38 \\
\hline
\end{tabular}

Table 2: Foeto-maternal outcomes and mode of delivery in study and control group.

\begin{tabular}{|c|c|c|c|c|c|}
\hline \multirow{2}{*}{$\begin{array}{l}\text { Outcome } \\
\text { Variables } \\
\text { Maternal variables }\end{array}$} & \multicolumn{2}{|c|}{$\begin{array}{l}\text { Study } \\
\text { Group } \\
(\mathrm{N}=43)\end{array}$} & \multicolumn{2}{|c|}{$\begin{array}{l}\text { Control } \\
\text { Group } \\
(\mathrm{N}=105)\end{array}$} & \multirow[t]{2}{*}{$\begin{array}{l}\text { p- } \\
\text { value }\end{array}$} \\
\hline & No. & $\%$ & No. & $\%$ & \\
\hline Hypothyroidism & 08 & 18.61 & 08 & 7.61 & 0.02 \\
\hline GHTN & 02 & 4.65 & 05 & 4.76 & 0.977 \\
\hline $\mathrm{PE}$ & 01 & 2.33 & 03 & 2.86 & 0.856 \\
\hline PPROM & 02 & 4.65 & 05 & 4.76 & 0.977 \\
\hline \multicolumn{6}{|l|}{ Foetal variables } \\
\hline Miscarriage & 0 & 0 & 01 & 0.95 & 0.521 \\
\hline Prematurity & 11 & 25.58 & 17 & 16.19 & 0.338 \\
\hline SGA/IUGR & 10 & 23.25 & 19 & 18.09 & 0.473 \\
\hline 5 min APGAR <7 & 01 & 2.32 & 01 & 0.95 & 0.511 \\
\hline NICU Admission & 03 & 6.97 & 02 & 1.91 & 0.121 \\
\hline \multicolumn{6}{|l|}{ Mode of delivery } \\
\hline Vaginal delivery & 35 & 81.40 & 78 & 74.29 & 0.35 \\
\hline Caesarean section & 08 & 18.60 & 26 & 24.76 & 0.35 \\
\hline $\begin{array}{l}\text { Caesarean } \\
\text { section for foetal } \\
\text { distress }\end{array}$ & 04 & 9.30 & 04 & 3.80 & 0.04 \\
\hline GHTN-Gestational & P & II, & 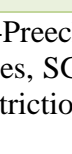 & O & 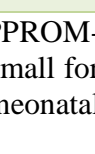 \\
\hline
\end{tabular}

The mean TSH values at recruitment and at term/delivery were higher in the study group as compared to the control 
group, although the difference was not statistically significant, Table 3.

Table 3: Mean serum TSH concentration in study and control group.

\begin{tabular}{|llll|}
\hline $\begin{array}{l}\text { Serum TSH } \\
(\mathrm{mIU} / \mathrm{L})\end{array}$ & $\begin{array}{l}\text { Study } \\
\text { group } \\
(\mathbf{n = 4 3})\end{array}$ & $\begin{array}{l}\text { Control } \\
\text { group } \\
(\mathbf{n}=\mathbf{1 0 5})\end{array}$ & $\mathbf{p}$-value \\
\hline At recruitment & 2.44 & 2.11 & 0.119 \\
\hline At term/delivery & 3.72 & 3.65 & 0.851 \\
\hline
\end{tabular}

\section{DISCUSSION}

Antithyroid antibodies are reported in around $18 \%$ of pregnant women and are associated with development of hypothyroidism during pregnancy and adverse pregnancy outcome even in euthyroid women. ${ }^{9}$ This may be attributed to the reduced ability of thyroid gland to adjust with the increased demand as pregnancy progresses. ${ }^{2}$

The prevalence of TPO-Ab positivity in euthyroid pregnant women observed in the present study was $11.3 \%$. This observation is similar to those of Ijima et al who reported TPO positivity in $10.6 \%$ of pregnant euthyroid Japenese women. ${ }^{14}$ Negro et al and Ghafoor et al also observed a similar prevalence of $11.7 \%$ and $11.2 \%$, in euthyroid pregnant Italian and Pakistani women respectively. ${ }^{2,3}$ Haddow et al also reported TPO positivity in $12.9 \%$ euthyroid American pregnant women. ${ }^{15}$ However the observation differs from those reported by Gayathri et al and Ghanavati et al who found a lower prevalence of TPO-Ab positivity in euthyroid pregnant women. ${ }^{1,16}$ In a systematic review and metaanalyses of published literature by Thangaratinam et al the reported prevalence of TPO-Ab in euthyroid pregnant women varied between $5.4 \%$ and $31 \% .^{6}$

In nearly $18.61 \%$ of thyroid peroxidase antibody positive women in our study, the TSH levels at term/delivery had crossed the upper limit of the euthyriod range $(>5.2 \mu \mathrm{ml} / \mathrm{l})$ as compared with thyroid peroxidase antibody negative women, the difference was statistically significant, $p=0.02$. Glinoer et al found that the progression of pregnant women to subclinical hypothyroidism can be predicted by the serum TSH levels and TPO-Ab titres in the first trimester. They also recommended the use of these parameters to identify high risk women and advised for close monitoring of thyroid functions of these women and administration of L-thyroxine to the selected cases. ${ }^{17}$ Negro et al reported development of hypothyroidism at term in $19 \%$ of euthyroid TPO-Ab positive women. Their study suggested that the women who are TPO positive and euthyroid in early pregnancy carry a significant risk of developing hypothyroidism with progressing gestation, despite a marked reduction in antibody titres. They found progressive increase in the serum TSH concentration of euthyroid TPO positive women, from a mean of 1.7 $\mathrm{mIU} / \mathrm{L}$ at 12 th week to $3.5 \mathrm{mIU} / \mathrm{L}$ at term. ${ }^{2} \mathrm{We}$ also observed increase in the mean serum TSH level from
$2.44 \mathrm{mIU} / \mathrm{L}$ at the time of recruitment in the study $(<20$ weeks) gestation to $3.72 \mathrm{mIU} / \mathrm{L}$ at term/delivery. The results of the present study are in accordance with the previous studies and confirm that the requirement of thyroid hormones increase with advancing gestation.

\section{Association of TPO-Ab positivity with foeto-maternal outcome}

Except for the development of hypothyroidism and increased risk of caesarean section for foetal distress, our study failed to find any association of TPO-Ab positivity in euthyroid women with the other maternal and foetal variable studied. Ghanavati et al, Mannisto et al and Negro et al also found no difference in the hypertensive disorders or gestational diabetes amongst euthyroid TPO$\mathrm{Ab}$ positive and negative women. , $2,18-20^{-1}$

Negro et al and Mannisto et al have reported no association between TPO positivity and abruptio placentae. ${ }^{2,20}$ However, Ghanavati et al observed four fold risk of developing placental abruption in women positive for TPO-Ab (1.0\% vs $0.3 \%) .{ }^{1}$ In present study, none of the women in either of the groups had placental abruption. This could be because of low incidence of abruptio placentae and small sample size of our study population.

We observed that the overall caesarean section rates in the TPO-Ab positive and negative group were comparable $(18.6 \%$ and $24.76 \%$, respectively, $\mathrm{p}=0.35)$. However, the incidence of caesarean section for foetal distress was found to be statistically higher in the study group as compared to the control group $(9.3 \%$ and $3.8 \%$, respectively, $\mathrm{p}=0.04)$. Ghanavati et al did not find any significant difference in overall incidence of LSCS $(25 \%$ and $25 \%$, respectively, $\mathrm{p}=0.58$ ) and the rate of LSCS for FD was also comparable in their study even after adjustment of demographic differences (4\% and $4 \%$, respectively, $\mathrm{p}=0.71) .{ }^{1}$ Negro et al also reported no association of caesarean rates with TPO positivity (22.45\% and $20.9 \%$ respectively, $\mathrm{p}=0.560) .{ }^{19}$

In the present study, only one woman in the control group and none in the study group suffered from miscarriage. Stagnaro Green et al reported a statistically significant doubling in the miscarriage rate in TPO-Ab positive euthyroid women as compared to TPO negative controls (17\% and $8.4 \%$, respectively). ${ }^{21}$ Similar observations were made by Glinoer et al who found that the women with thyroid autoimmunity are at an increased risk of having spontaneous miscarriage when compared with controls, $13.3 \%$ and $3.3 \%$, respectively, $\mathrm{p}<.001 .{ }^{17}$ Ijima et al and Ghafoor et al have also made similar observations (10.4\% vs $5.5 \%, \mathrm{p}<0.05$ and $36.3 \%$ vs $1.8 \%, \mathrm{p}<0.01$, respectively). ${ }^{3,14}$ Negro et al reported a higher incidence of miscarriage amongst TPO positive euthyroid women as compared to TPO negative women, $3.8 \%$ and $2.4 \%$, respectively, $\mathrm{p}<0.01$. They also observed the reduction in 
spontaneous miscarriage by administration of Lthyroxine therapy in euthyroid TPO-Ab positive women. ${ }^{2}$

The difference in our observation is probably because of smaller size of the present study. Besides, in the study by Negro et al, all the miscarriages in the TPO positive group and most (19 of 20) in the TPO negative group occurred during the first trimester. ${ }^{2}$ However, in the present study the mean gestational age at presentation to the antenatal clinic was in the second trimester, 15.5 weeks and 16.2 weeks, in study and control group, respectively, and by this time most of the miscarriages would have already occurred.

Author found that the incidence of prematurity in the TPO positive group was higher as compared to TPO negative group, $25.58 \%$ and $16.2 \%$, respectively, however the difference was not statistically significant, $\mathrm{p}=0.338$. Similar observations were reported by some authors who found comparable rates of preterm delivery in study and control groups. ${ }^{1,18,22}$ However, other authors found a significantly increased risk of preterm delivery in euthyroid TPO-Ab positive women. ${ }^{2,3,19,23}$ Negro et al also reported the reduction of adverse foetal outcome by administration of L-thyroxine. ${ }^{2}$ Thangaratinam et al reported a strong association of TPO-Ab positivity with poor obstetric outcomes, for both miscarriage and preterm birth. ${ }^{6}$

The incidence of SGA/IUGR in our study group was higher than in control group, $23.3 \%$ and $18.1 \%$ respectively, however the difference was not statistically significant, $\mathrm{p}=0.47$. These observations are similar to those of Ghanavati et al, Mannisto et al and Negro et al. ${ }^{1,18,19}$ However, Ijima and colleagues reported increased rate of SGA in euthyroid TPO positive women when compared to controls, $7.1 \%$ and $3.4 \%$, respectively. ${ }^{14}$

Similar to the observation by previous studies, we also found no significant difference in low Apgar score and NICU admissions between TPO positive and negative euthyroid women. ${ }^{1,20}$ However, Negro et al reported a significantly higher incidence of RDS (3.3 vs $1.2 \%$, p$0.005)$ in women who were TPO positive. ${ }^{20}$

Author had one case of IUD at 31 wks in the TPO positive group and none in the control group. There was no case of stillbirth/NND in either of the groups. Ghanavati et al and Negro et al also did not find any association of stillbirth/NND with TPO positivity, whereas Mannisto et al observed 2 to 3 fold greater perinatal mortality in the infants of thyroid autoantibodypositive mothers. ${ }^{1,19,20}$

Euthyroid pregnant women who are TPO-Ab positive have an increased risk of developing hypothyroidism at term/delivery. Except for repeat testing for thyroid hormones, no additional foeto-maternal monitoring is required in these women.
Funding: No funding sources

Conflict of interest: None declared

Ethical approval: The study was approved by the Institutional Ethics Committee

\section{REFERENCES}

1. Abbassi-Ghanavati M, Casey BM, Spong CY, McIntire DD, Halvorson LM, Cunningham FG. Pregnancy outcomes in women with thyroid peroxidase antibodies. Obstet Gynaecol. 2010;116(2):381-6.

2. Negro R, Formoso G, Mangieri T, Pezzarossa A, Dazzi D, Hassan H. Levothyroxine treatment in euthyroid pregnant women with autoimmune thyroid disease: effects on obstetrical complications. J Clin Endocrinol Metab. 2006;91(7):2587-91.

3. Ghafoor F, Mansoor M, Malik T, Malik MS, KhanAU, Edwards $\mathrm{R}$ et al. Role of thyroid peroxidase antibodies in the outcome of pregnancy. $\mathrm{J}$ Coll Physicians Surg Pak. 2006;16(7):468-71.

4. Casey BM, Dashe JS, Spong CY, McIntire DD, Leveno KJ, Cunningham GF. Perinatal significance of isolated maternal hypothyroxinemia identified in the first half of pregnancy. Obstet Gynecol. 2007;109(5):1129-35.

5. Pop VJ, Brouwers EP, Vader HL, Vulsma T, van Baar AL, de Vijlder JJ. Maternal hypothyroxinaemia during early pregnancy and subsequent child development: a 3-year follow up study. Clin Endocrinol (oxf). 2003;59:282-8.

6. Thangaratinam S, Tan A, Knox E, Kilby MD, Franklyn J, Coomarasamy A. Association between thyroid autoantibodies and miscarriage and preterm birth:meta-analyses of evidence. BMJ. 2011;342:1-8.

7. Prummel MF, Wiersinga WM. Thyroid autoimmunity and miscarriage. Eur J Endocrinol. 2004;150(5):751-5.

8. Glinoer D. Editorial: Miscarriage in women with positive anti-TPO antibodies: Is thyroxine the answer. J Clin Endocrinol Metab. 2006;91(7):25002.

9. Alexander EK, Pearce EN, Brent GA, Brown RS, Chen H, Dosiou C, et al. 2017 Guidelines of the American Thyroid Association for the Diagnosis and Management of Thyroid Disease During Pregnancy and the Postpartum. Thyroid. 2017;27(3):315-89.

10. Poppe K, Glinoer D. Thyroid autoimmunity and hypothyroidism before and during pregnancy. Hum Reprod Update. 2003;9(2):149-61.

11. Banerjee S. Thyroid disorders in pregnancy. J Assoc Physicians India 2011; 59(suppl):32-34.

12. Stagnaro-Green A, Abalovich M, Alexander E, Azizi F, Mestman J, Negro R et al. Guidelines of the American Thyroid association for the diagnosis and management of thyroid disease during pregnancy and postpartum. Thyroid 2011;21(10):1-46.

13. Marwaha RK, Chopra S, Gopalakrishnan S, Sharma B, Kanwar RS, Sastry A et al. Establishment of 
reference range for thyroid hormones in normal pregnant Indian women. BJOG 2008;115(5):602-06.

14. Iijima $T$, Tada $H$, Hidaka $Y$, Mitsuda N, Murata $Y$, Amino N. Effects of autoantibodies on the course of pregnancy and fetal growth. Obstet Gynecol 1997;90(3):364-69.

15. Haddow JE, Cleary-Goldman J, McClain MR, Palomaki GE, Neveux LM, Lambert-Messerlian G, et al. Thyroidperoxidase and thyroglobulin antibodies in early pregnancy and preterm delivery. Obstet Gynecol 2010;116(1):58-62.

16. Gayathri R, Lavanya S, Raghwan K. Subclinical hypothyroidism and autoimmune thyroiditis in pregnancy. J Assoc Physicians India 2009;57:691-3.

17. Glinoer D, Rihi M, Grün JP, Kinthaert J. Risk of subclinical hypothyroidism in pregnant women with asymptomatic autoimmune thyroid disorders. J Clin Endocrinol Metab. 1994;79(1):197-04.

18. Männistö T, Vääräsmäki $\mathrm{M}$, Pouta $\mathrm{A}$, Hartikainen AL, Ruokonen A, Surcel HM, et al. Perinatal outcome of children born to mothers with thyroid dysfunction or antibodies: a prospective populationbased cohort study. J Clin Endocrinol Metab. 2009;94(3):772-9.

19. Negro R, Schwartz A, Gismondi R, Tinelli A, Mangieri T, Stagnaro-Green A. Thyroid antibody positivity in the first trimester of pregnancy is associated with negative pregnancy outcomes. J Clin Endocrinol Metab. 2011;96(6):E920-24.
20. Männistö T, Vääräsmäki M, Pouta $A$, Hartikainen AL, Ruokonen A, Surcel HM et al. Thyroid dysfunction and autoantibodies during pregnancy as predictive factors of pregnancy complications and maternal morbidity in later life. J Clin Endocrinol Metab. 2010;95(3):1084-94.

21. Stagnaro-Green A, Roman SH, Cobin RH, Harazy E, Alvarez-Marfany M, Davies TF. Detection of at-risk pregnancy by means of highly sensitive assays for thyroid autoantibodies. JAMA. 1990;264(11):14227.

22. Stagnaro-Green A, Chen X, Bogden JD, Davies TF, Scholl TO. The thyroid and pregnancy: a novel risk factor for very preterm delivery. Thyroid. 2005;15(4):351-7.

23. He X, Wang $\mathrm{P}$, Wang $\mathrm{Z}, \mathrm{He} \mathrm{X}, \mathrm{Xu} \mathrm{D}$, Wang B. Thyroid antibodies and risk of preterm delivery: a meta-analysis of prospective cohort studies. Eur J Endocrinol. 2012;167(4):455-64.

Cite this article as: Gulati K, Sharma M, Bharti R, Biswas K, Batra A, Aggarwal A et al. Thyroid peroxidase antibody positivity among euthyroid pregnant women and its association with foetomaternal outcome. Int J Reprod Contracept Obstet Gynecol 2018;7:1400-5. 